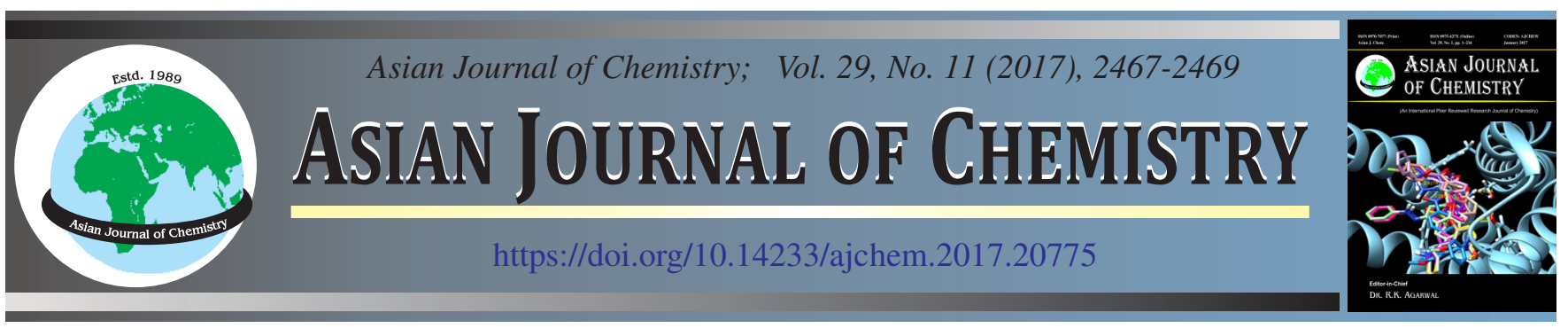

\title{
Evaluation of in vitro Cytotoxicity of Essential Oil from Clausena dentata (Willd) Grown in Western Ghats Region, South India
}

Kathirvel Poonkodi ${ }^{*}$, Ramasamy Anitha, Sundaramoorthi Vasanthamani, Jaganathan Karthika and Velusamy Tamilselvi

PG Department of Chemistry, NGM College, Pollachi-642 001, India

*Corresponding author: E-mail: poonks.che@gmail.com

Received: 10 May 2017;

Accepted: 15 July 2017;

Published online: 29 September 2017;

AJC-18573

The present study examines the in vitro cytotoxicity of essential oil from Clausena dentata against the HeLa Cancer cell line and NIH 3 T3
normal fibroblast by using methyl thiazol tetrazolium assay. The hydrodistilled essential oil of $C$. dentata was analyzed by GC-MS and
results revealed that the chemical composition of essential oil of $C$. dentata contains 23 compounds. The major chemical compositions of
oil were sabinene $(19.70 \%), \beta$-caryophyllene oxide $(17.90 \%)$, cis-(R,2R)-hydroxy-2-methylindane $(18.40 \%)$ and ethanone 1,2 -hydroxy-
5 -methylphenyl $(7.85 \%)$. The minor compounds were $\alpha$-myrcene $(3.48 \%)$, spathulenol $(2.44 \%)$, isospathulenol $(1.22 \%)$, caryophyllene
$(1.08 \%)$, curzerene $(1.01 \%)$, nerol $(0.23 \%), \alpha$-pinene $(0.65 \%)$, neryl acetate $(0.47 \%)$ etc. The in vitro cytotoxicity was investigated by
methyl thiazol tetrazolium assay against HeLa and NIH-3T3 cell lines with different concentrations of essential oil $(18.5-300 \mu \mathrm{g} / \mathrm{mL})$.
The results revealed that the essential oil showed concentration dependant activity against both employed cell lines. The IC 50 value of HeLa
and NIH3T3 were 75.3 and $99.83 \mu \mathrm{g} / \mathrm{mL}$, respectively.
Keywords: Clausena dentata, Sabinene, $\beta$-Caryophyllene oxide, HeLa and NIH3T3 cell lines.

\section{INTRODUCTION}

According to World health organization (WHO), cancer is the second most major disease in the world. Now days $60 \%$ of the available cancer drugs are derived from plant based pro-ducts, vinblastine and vincristine are very famous cancer drugs for long period. Still many commercial drugs are emerging for treating cancer with enormous side effects and unaffordable cost. Recently much research is focused on plant based products for anticancer property with less adverse effects, low cost and more efficiency. Clausena dentata (Wild) is a small tree belongs to Rutaceae found in Asia including China, Sri Lanka and India [1]. It is called kattukariveppilai in Tamil, due to its medicinal and nutritional value the local people of Valparai, Yercaud and Boda Hills are used for many purposes [2]. Traditionally the leaf juice is applied to the injured eye and leave paste is used for curing wounds $[3,4]$. The chemical composition of essential oil of the $C$. dentata in different part of the world were sabinene, borneol, $\delta$-cadinol, $\beta$-bisabolol, biofloratriene $\alpha$-pinene, $\beta$-amyrine $\beta$-caryophyllene and $\beta$ pinene [5-8]. The secondary metabolites like $\alpha$-clausenan, rosesenan ( $\alpha$-clausenan), diclausenans $\mathrm{A}$ and $\mathrm{B}$ and furano terpenes [9]. Two coumarins were isolated and named dentatin and nordentatin from root bark of $C$. dentata by spectral identification [10]. Saponins and terpenoids were found in C. dentata plant extracts. The ethanol extract of this plant was evaluated for hepatotoxicity study in rats [11]. The essential oil has ovicidal, mosquito repellent and larvicidal activities $[5,6]$. From the literature survey, there are only few reports are available for its essential oil composition and its pharmacological activities. There is no report is available for in vitro cytotoxicity of essential oil. In this view, our present investigation was aimed to evaluate the chemical composition and in vitro cytotoxicity of essential oil of leaves of $C$. dentata.

\section{EXPERIMENTAL}

Fresh leaves of $C$. dentata were collected from Valparai hills between the periods of December-January 2017. The plant material was identified and authenticated by Department of Botany, NGM College, Pollachi, Coimbatore, India. The voucher specimen (16CHE009) was preserved in the Chemistry Department.

Isolation of essential oil: About $500 \mathrm{~g}$ of fresh leaves was subjected to hydrodistillation using Clevenger type apparatus for $3 \mathrm{~h}$. The oil obtained was dried over anhydrous sodium sulphate and stored in a container and kept in freezer until GC-MS analysis.

GC-MS analysis: The gas chromatogram was recorded in Agilent make with GC 7890 with Mass detector 5975C with DB-5 column having $95 \%$ polydimethylsiloxane with $5 \%$ 
phenyl group. For GC/MS detection, electron ionization with ionization energy of $70 \mathrm{eV}$ was used. Helium gas $(99.999 \%)$ was used as the carrier gas at a constant flow rate of $1 \mathrm{~mL} / \mathrm{min}$ and injection volume was $1 \mu \mathrm{L}$ (split ratio 10:1). Injector temperature was $250{ }^{\circ} \mathrm{C}$; ion-source temperature $260{ }^{\circ} \mathrm{C}$. The oven temperature was programmed from $70^{\circ} \mathrm{C}$ (isothermal for $2 \mathrm{~min}$ ), with an increase of $25^{\circ} \mathrm{C} / \mathrm{min}$, to $150{ }^{\circ} \mathrm{C}$ (hold $10 \mathrm{~min}$ ), then $25^{\circ} \mathrm{C} / \mathrm{min}$ to $260^{\circ} \mathrm{C}$, ending with $40 \mathrm{~min}$ isothermal at $260{ }^{\circ} \mathrm{C}$. Total run time was $59.6 \mathrm{~min}$. Software adopted to handle mass spectra and chromatogram was a chemstation and compounds are identified from the NIST library match. Petroleum ether, ethyl acetate and methanol were purchased from Finar chemicals.

In vitro cytotoxicity activity by methyl thiazol tetrazolium assay: Human cervical cancer cell line (HeLa) and mouse embryonic fibroblast (NIH-3T3) was obtained from National Centre for Cell Science (NCCS), Pune. The HeLa and NIH-3T3 cells were grown in eagles minimum essential medium (EMEM) containing $10 \%$ fetal bovine serum (FBS) and NIH 3T3 fibroblasts were grown in dulbeccos modified eagles medium (DMEM) containing with $10 \%$ FBS. For the screening experiment, the cells were seeded into 96-well plates in $100 \mu \mathrm{L}$ of the respective medium containing $10 \% \mathrm{FBS}$, at plating density of 10,000 cells/well and incubated at $37{ }^{\circ} \mathrm{C}$, $5 \% \mathrm{CO}_{2}, 95 \%$ air and $100 \%$ relative humidity for $24 \mathrm{~h}$ prior to addition of essential oil. The essential oil was solubilized in dimethylsulfoxide and diluted in the respective medium containing $1 \%$ FBS. After $24 \mathrm{~h}$, the medium was replaced with respective medium with $1 \%$ FBS containing the oil at various concentrations (12.5 to $300 \mu \mathrm{g} / \mathrm{mL})$ and incubated at $37{ }^{\circ} \mathrm{C}$, $5 \% \mathrm{CO}_{2}, 95 \%$ air and $100 \%$ relative humidity for $48 \mathrm{~h}$. Triplicate was maintained and the medium containing without oil served as control. After $48 \mathrm{~h}, 10 \mu \mathrm{L}$ of methyl thiazol tetrazolium $(5 \mathrm{mg} / \mathrm{mL})$ in phosphate buffered saline (PBS) was added to each well and incubated at $37^{\circ} \mathrm{C}$ for $4 \mathrm{~h}$. The medium with methyl thiazol tetrazolium was then flicked off and the formed formazan crystals were solubilized in $100 \mu \mathrm{L}$ of DMSO and then measured the absorbance at $570 \mathrm{~nm}$ using micro plate reader [12]. Non-linear regression graph was plotted between $\%$ cell inhibition and $\log _{10}$ concentration and $\mathrm{IC}_{50}$ was determined using Graph pad prism software.

\section{RESULTS AND DISCUSSION}

GC-MS analysis: The essential oil from the leaves of $C$. dentata was analyzed by GC-MS. $C$. dentata essential oil was yellow in colour. A total of 23 compounds representing $92.3 \%$ of the essential oil was identified. The major chemical compositions of oil were sabinene (19.70\%), $\beta$-caryophyllene oxide (17.90\%), cis-(R,2R)-hydroxy 2-methylindane (18.40\%) and car-2-en-4-one (7.85\%). The minor compounds were $\alpha$-myrcene $(3.48 \%)$, spathulenol $(2.44 \%)$, isospathulenol (1.22\%), himoquinone D $(1.38 \%)$, caryophyllene $(1.08 \%)$, curzerene $(1.01 \%)$, nerol $(0.23 \%), \alpha$-pinene $(0.65 \%)$, neryl acetate $(0.47 \%)$, etc. The chemical composition of essential oil from pasirimalai forest region showed 12 components and major compounds were sabinene (28.57\%), borneol (14.62), $\delta$-cadinol (12.49), $\beta$-bisabolol (15.56\%) and biofloratriene (18.54\%) [5]. Vietnamese plant leaf essential oil contains $\alpha$-pinene $(21.7 \%)$, sabinene (18.35\%), $\beta$-amyrine $(14.3 \%) \beta$-caryophyllene $(8.9 \%)$ and $\beta$-pinene are the major compounds [7]. Similarly, 14 different compounds were obtained by GC-MS analysis in which sabinene of $21.27 \%$, biofloratriene of $19.61 \%$, borneol of $18.34 \%$ and $\beta$-bisabolol of $17.68 \%$ were the major compounds [6]. The chemical composition of essential oil of $C$. dentata from Valparai Hills showed diffe-rent composition may be due to different climatic conditions, seasonal and geographical reasons [13].

In vitro cytotoxity: We employed methyl thiazol tetrazolium (MTT) assay, a simple and reliable technique, which measures cell viability for screening the cytotoxic activity. The viability of cancer cells after incubation with different concen-

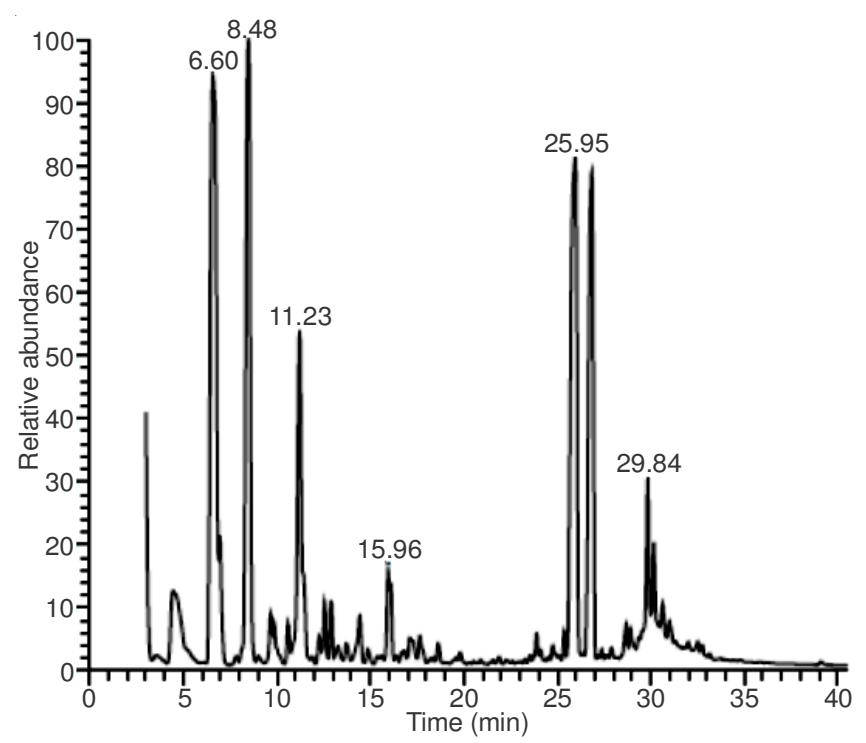

Fig. 1. GC-MS Chromatogram of essential oil of C. dentata

\begin{tabular}{|c|c|c|c|}
\hline \multicolumn{4}{|c|}{$\begin{array}{c}\text { TABLE-1 } \\
\text { GC-MS ANALYSIS OF VOLATILE } \\
\text { COMPOSITION OF ESSENTIAL OIL OF C. dentate }\end{array}$} \\
\hline $\begin{array}{l}\text { S. } \\
\text { No. }\end{array}$ & Compound name & RT & $\begin{array}{c}\text { Composition } \\
(\%)\end{array}$ \\
\hline 1 & Nerol & 3.58 & 0.23 \\
\hline 2 & $\alpha$-Myrcene & 4.46 & 3.48 \\
\hline 3 & Sabinene & 6.58 & 19.70 \\
\hline 4 & Propanal, 2-metyl-3-phenyl & 6.96 & 0.65 \\
\hline 5 & $\beta$-Caryophyllene oxide & 8.48 & 17.19 \\
\hline 6 & 2,6-Dimetyl-2,4,6-octatrienedial & 9.68 & 1.32 \\
\hline 7 & Neryl acetate & 10.61 & 0.47 \\
\hline 8 & (+)-Car-2-en-4-one & 11.23 & 7.85 \\
\hline 9 & Thymoquinone & 12.56 & 1.38 \\
\hline 10 & Germacrene D & 12.91 & 0.77 \\
\hline 11 & Cubedol & 13.27 & 0.34 \\
\hline 12 & e-Cadinene & 13.72 & 0.34 \\
\hline 13 & Caryophyllene & 14.45 & 1.08 \\
\hline 14 & Hedycaryol & 14.88 & 0.28 \\
\hline 15 & (+)Spathulenol & 15.96 & 2.44 \\
\hline 16 & Humulene oxide & 16.81 & 0.28 \\
\hline 17 & Isospathulenol & 17.12 & 1.22 \\
\hline 18 & $\alpha$-Cadinol & 17.67 & 0.53 \\
\hline 19 & Ursuline & 23.91 & 0.55 \\
\hline 20 & Phytol & 25.37 & 0.33 \\
\hline 21 & $\begin{array}{l}\text { cis-(1R,2R)-1-Hydroxy-2- } \\
\text { methylindane }\end{array}$ & 25.97 & 18.40 \\
\hline 22 & 6-Methyl-4-indanol & 26.85 & 14.45 \\
\hline 23 & Curzerene & 28.68 & 1.01 \\
\hline
\end{tabular}


tration of $C$. dendata essential oil are reported in Fig. 2. The effect of $C$. dentata essential oil on the viability of HeLa and NIH 3 T3 cell lines showed concentration dependant activity. Data showed that incubation with different concentrations of oil affected the viability of human cervical cancer cell line (HeLa) and NIH $3 \mathrm{~T} 3$ mouse embryonic fibroblasts. The $\mathrm{IC}_{50}$ values of both cell lines were 75.33 and $99.83 \mu \mathrm{g} / \mathrm{mL}$ respectively. The results revealed that the normal cell line NIH-3T3 requires more concentration compared to HeLa cancer cell line which showed that the essential oil of $C$. dentata is less toxic towards the normal cell line. The essential oil of $C$. dentata possesses anticancer activity. It may be attributed due to the presence of terpenes like caryophylline oxide, sabanine and pinene, etc. There is no report in the literature for cytotoxicity of $C$. dentata leave essential oil, this is the first kind of report against anticancer activity.
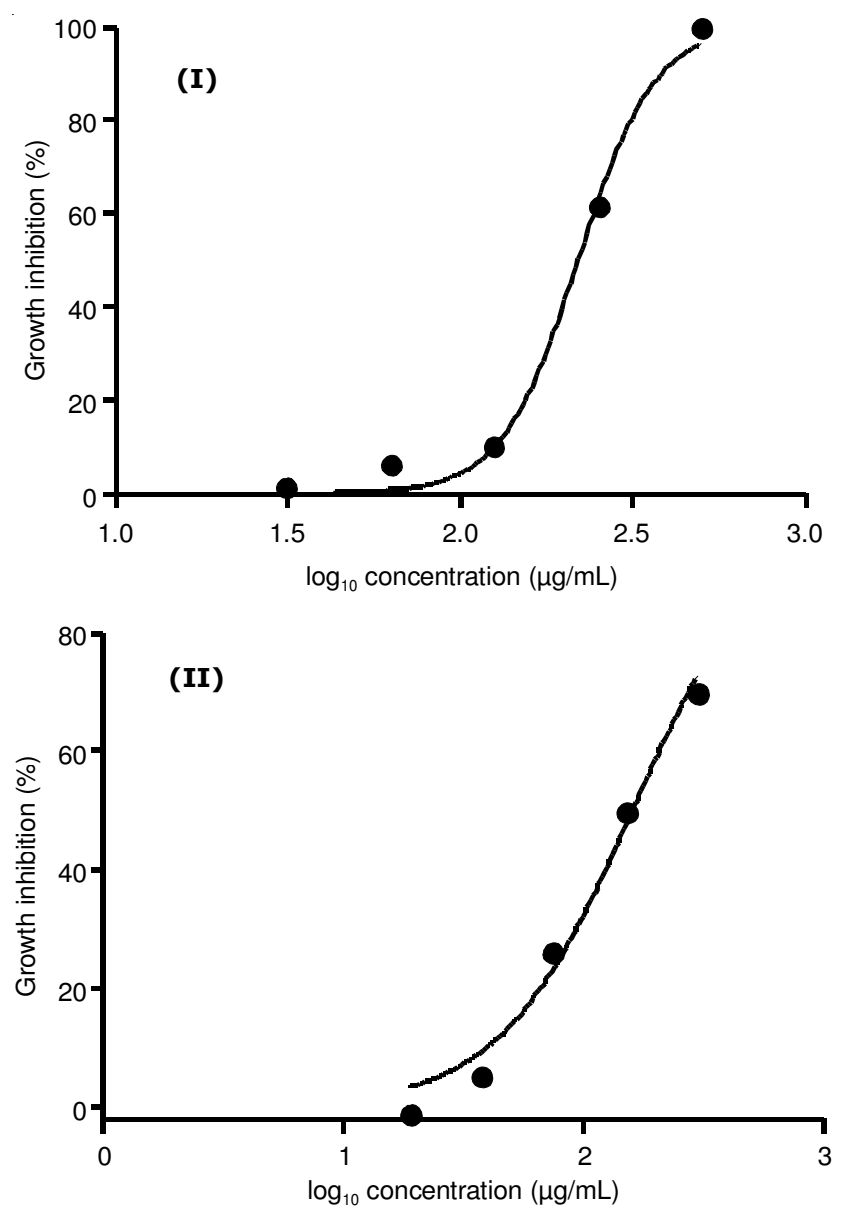

Fig. 2. Effect of essential oil of C. dentata against (I) HeLa cancer cell line and (II) NIH3T3 normal cell line

\section{Conclusion}

The chemical composition of essential oil of $C$. dentata grown in Western ghats region was analyzed by GC-MS method. A total of 23 components was identified. Sabanene (19.70\%), $\alpha$-myrcene $(3.48 \%), \beta$-caryophyllene oxide $(17.90 \%)$ and ethanone, car-2-en-4-one (7.85\%) were the major compounds in $C$. dentata. In vitro cytotoxicity activity of essential oil of C. dentata was evaluated against HeLa cancer cell line and NIH-3T3 by methyl thiazol tetrazolium assay. Essential oil showed concentration dependent activity on both cell lines. The $\mathrm{IC}_{50}$ value is 75.3 and $99.833 \mu \mathrm{g} / \mathrm{mL}$ respectively. From the results, $C$. dentata essential oil has significant anticancer activity this may attributed to the presence of important terpenoids.

\section{REFERENCES}

1. S.R. Agarwal, eds.: S.K. Jain Glimpses of Indian Ethnobotany, Oxford and IBH Publishing Co., New Delhi, pp. 3-12 (1981).

2. R. Zafar, Medicinal Plants of India, CBS, Delhi, pp. 48-61 (1994).

3. T. Apparanantham and V. Chelladurai, Anc. Sci. Life, 5, 412 (1986).

4. J. Nithyadevi and R. Sivakumar, Int. Lett. Nat. Sci., 32, 77 (2015); https://doi.org/10.18052/www.scipress.com/ILNS.32.77.

5. K. Krishnappa, K. Elumalai, A. Anandan, M. Govindarajan and T. Mathivanam, Int. J. Recent Sci. Res., 8, 188 (2009).

6. S. Rajkumar and A. Jabanesan, Eur. Rev. Med. Pharmacol. Sci., 14, 231 (2010).

7. H.D. Trung, T.D. Thang, P.H. Ban, T.M. Hoi, D.N. Dai and I.A. Ogunwande, Nat. Prod. Res., 28, 622 (2014); https://doi.org/10.1080/14786419.2014.888555.

8. G. Ramkumar, S. Karthi, R. Muthusamy, D. Natarajan and M.S. Shivakumar, Parasitol. Res., 114, 1139 (2015); https://doi.org/10.1007/s00436-014-4288-8

9. G.S.R. Subba Rao, B. Yadagiri, S.N. Rao and G.R. Mallavarapu, Phytochemistry, 23, 2962 (1984); https://doi.org/10.1016/0031-9422(84)83055-1.

10. T.R. Govindachari, P.S. Subramaniam, N. Muthukumaraswamy and B.R. Pai, Tetrahedron, 24, 753 (1968); https://doi.org/10.1016/0040-4020(68)88024-X.

11. T. Mosmann, J. Immunol. Methods, 65, 55 (1983); https://doi.org/10.1016/0022-1759(83)90303-4.

12. S.V. Rajesh, B. Rajkapoor, R. Senthil Kumar and K. Raju, Pak. J. Pharm. Sci., 22, 90 (2009).

13. P. Kathirvel and S. Ravi, Nat. Prod. Res., 26, 1112 (2012); https://doi.org/10.1080/14786419.2010.545357. 